\title{
К ВОПРОСУ О ПРАВОВОМ СТАТУСЕ РОССИЙСКОЙ ПОЛИЦИИ И ПРОБЛЕМЫ ЕГО РЕАЛИЗАЦИИ В АДМИНИСТРАТИВНОЙ ДЕЯТЕЛЬНОСТИ
}

\begin{abstract}
Аннотация: В статье отмечается, что в процессе своей деятельности органы внут-ренних дел (полиции) осуществляют значительное количество администра-тивных функций, при реализации которых они в соответствии со своей ком-петенцией вступают в особые правовые отношения с гражданами, государст-венными и общественными организациями и их должностными лицами. Ис-ходя из предмета статьи, в ней раскрывается характер административных функций, реализуемых органами внутренних дел. В работе предложена классификация прав и обязанности полиции, которые позволяют раскрыть сущность и содержание ее деятельности, на основании проведенного иссле-дования формулируются предложения по совершенствованию механизма реализации прав и обязанностей полиции. Методологическую основу статьи составили современные достижения теории познания. В процессе исследования применялись теоретический, общефилософские методы (диалектика, системный метод, анализ, синтез, аналогия, дедукция, наблюдение, моделирование), традиционно правовые методы (формально-логический), а также методы, используемые в конкретно-социологических исследованиях (статистические, экспертные оценки и др.). В статье отмечается, что в компетенцию полиции входят: защита лич-ности, общества, государства от противоправных посягательств; предупреж-дение и пресечение преступлений и административных правонарушений; производство по делам об административных правонарушениях, исполнение административных наказаний; обеспечение правопорядка в общественных местах; обеспечение безопасности дорожного движения и др.

Ключевые слова: полиция, МВД, статус, права, обязанности, реализация, ОВД, сила, принуждение, правопорядок.
\end{abstract}

$\Pi$ рактически каждый этап социально-экономического и политического развития нашей страны ставит перед органами внутренних дел новые задачи в сфере охраны общественного порядка и обеспечении общественной безопасности. Новые вызовы и угрозы заставляют все время модернизировать полицейскую деятельность, осуществлять техническое и кадровое переоснащение органов внутренних дел. Несмотря на изменение форм и методов функционирования государственной власти, развитие демократических традиций и народовластия, сотрудник полиции, какую бы должность он ни занимал, остается основным представителем исполнительной власти, к которому в силу целого ряда объективных и субъективных причин вынуждены обращаться граждане и представители юридических лиц. В связи с этим необходимо непрерывно проводить работу по совершенствованию правовых и организационно-тактических основ деятельности органов внутренних дел. В современный период крайне важно проводить систематическую работу по укреплению морально-психологического климата в служебных коллективах органов внутренних дел, осуществлять подготовку и отбор квалифицированных и честных кадров, создавать для наиболее достойных и подготовленных сотрудников условия для их профессионального и нравственного роста. Именно эти, а также и целый ряд иных задач, связанных с повышением эффективности деятельности органов внутренних дел, стоят перед руководителями МВД России самого различного уровня.

Административная деятельность органов внутренних дел как направление исполнительнораспорядительной деятельности государственной власти занимает центральное место в деле охраны общественного порядка, обеспечении общественной и личной безопасности граждан. Традиционно считается, что более $90 \%$ рабочего времени сотрудников органов внутренних дел занимает именно административная деятельность, которая осуществляется с помощью самых различных форм и методов. Так, граждане в своей повседневной дея-

Статья подготовлена при информационной поддержке «Компании Консультант Плюс». 
тельности чаще всего сталкиваются с реализацией административной деятельности полиции, представители которой обеспечивают безопасность дорожного движения, осуществляют патрулирование на улицах и местах массового скопления и прохода граждан, обеспечивают безопасность пассажиров на различных видах транспорта. В рамках административной деятельности органы внутренних дел в целом и полиция в частности, осуществляют взаимодействие с различными органами государственной власти. Также нужно отметить, что в рамках административной деятельности органы внутренних дел предоставляют гражданам и юридическим лицам различные государственные услуги, например, в сфере обеспечения имущественной безопасности, разрешительной системы, информационного обеспечения и др.

Несмотря на важность этого направления административной деятельности органов внутренних дел, основное место в содержании этого вида деятельности занимают вопросы борьбы с преступностью, административными правонарушениями, а также защитой прав и свобод граждан. Перечисленные функции административной деятельности органов внутренних дел выполняют сформированные службы и подразделения полиции, которые в каждодневном и непрерывном режиме выполняют перечисленные выше задачи, ради которых собственно и создан полицейский аппарат современного Российского государства.

Следует отметить, что на острие самых серьезных проблем в сфере охраны общественного порядка и обеспечения общественной безопасности стоит участковый уполномоченный полиции, который, по сути, соединил в себе все основные функции полиции и в повседневном режиме реализует их на своем административном участке. Так сложилось, особенно в крупных городах, что именно от качества работы участкового уполномоченного полиции зависят уровень правопорядка в местах компактного проживания граждан, а также степень их личной и имущественной безопасности. Зачастую без помощи участкового уполномоченного полиции сотрудники уголовного розыска не в силах быстро раскрывать многие тяжкие преступления, а также задерживать подозреваемых в их совершении лиц.

Одним из важнейших подразделений полиции, осуществляющих административную деятельность, является патрульно-постовая служба. Работу патрульного полицейского, особенно на объектах транспорта и транспортной инфраструктуры, труд- но переоценить. Ее ежедневно наблюдают десятки тысяч граждан, и в случае возникновения какойлибо чрезвычайной ситуации, совершения административного правонарушения или преступления именно к сотруднику патрульно-постовой службы полиции граждане обращаются в целях получения от него необходимой помощи или оказания содействия в разрешении возникшей ситуации.

Другие службы полиции, осуществляющие внешнюю административную деятельность, также выполняют достаточно важные государственные функции, касающиеся, например, профилактики детской и подростковой деликтности. Полиция выполняет и целый ряд функций по обеспечению и исполнению миграционного законодательства, осуществляет контроль за работой частных детективных охранных структур и т.д.

Особое место в содержании административной деятельности полиции занимает административно-юрисдикционная деятельность, а именно производство по делам об административных правонарушениях. В этом направлении полиция наделяется все большей компетенцией, а административные наказания, применяемые полицией за самые различные правонарушения, с каждым годом становятся все более строгими. Именно поэтому любой сотрудник полиции обязан следить за изменениями в действующем законодательстве, которые касаются вопросов реализации административной ответственности.

Учитывая социальную нестабильность, а также систематически происходящие в различных частях нашей страны чрезвычайные события, которые вызваны природными и техногенными причинами, сотрудники полиции должны знать и умело применять тактические приемы и средства охраны общественного порядка и обеспечения общественной безопасности в условиях чрезвычайных ситуаций, массовых беспорядков, социальных волнений и т.д.

В связи с повышением социальной активности институтов гражданского общества, а также большого количества граждан, непосредственно заинтересованных в обеспечении правопорядка, органы внутренних дел должны и могут использовать свой потенциал в правоохранительных целях. По сути является аксиомой тот факт, что без поддержки и помощи общественности полиция едва ли сможет реализовать свои задачи в решении вопросов защиты прав граждан и борьбы с преступностью. Исходя из этого, в ходе осуществления административной деятельности полиция должна вовлекать достой- 
ных граждан в дело охраны общественного порядка, постоянно совершенствовать формы и методы своей работы в этом направлении.

Все направления внешней административной деятельности органов внутренних дел между собой взаимосвязаны и логически дополняют друг друга, следовательно, каждый сотрудник полиции должен знать основные направления административной деятельности органов внутренних дел.

Для того чтобы внешняя административная деятельность органов внутренних дел была эффективной, в сфере внутренних дел осуществляется внутриорганизационная административная деятельность, которая связана с материально-техническим обеспечением органов внутренних дел, подготовкой нормативных правовых актов, а также обеспечением законности и дисциплины среди личного состава органов внутренних дел.

Полиция в Российской Федерации сформирована для выполнения задач по защите личности, общества и государства от противоправных посягательств. Полиция также осуществляет предупреждение и пресечение преступлений и административных правонарушений, выявление и раскрытие преступлений, производство дознания по уголовным делам, а также розыск лиц. Отдельными направлениями деятельности полиции являются производство по делам об административных правонарушениях, исполнение административных наказаний, обеспечение правопорядка в общественных местах, а также обеспечение безопасности дорожного движения. Полиция осуществляет и целый ряд контрольных мероприятий, в частности касающихся соблюдения законодательства РФ в области оборота оружия, частной детективной (сыскной) и охранной деятельности. На полицию возложены задачи охраны имущества и объектов, в том числе на договорной основе, обеспечение государственной защиты потерпевших, свидетелей и иных участников уголовного судопроизводства, должностных лиц правоохранительных и контролирующих органов и ряда других определенных законодательством лиц.

Специальные структурные подразделения полиции осуществляют экспертно-криминалистическую деятельность. Для этого органы полиции имеют право: истребовать в установленном порядке от различных организаций образцы и каталоги их продукции, техническую и технологическую документацию, а также другие информационные материалы, необходимые для производства экспертиз; проводить исследования предметов и документов при наличии признаков подготавливаемого, совершаемого или совершенного противоправного деяния; проводить экспертизу (исследование) изъятых у граждан и должностных лиц документов, имеющих признаки подделки, а также вещей, изъятых из гражданского оборота.

Для решения вышеуказанных задач полиция наделяется объемом прав, которые условно можно подразделить на определенные группы.

Права правоохранительно-организационного характера. К этой группе относится, в частности, право требовать от граждан и должностных лиц прекращения противоправных действий, а также действий, препятствующих законной деятельности государственных и муниципальных органов, депутатов различного уровня, членов избирательных комиссий. Для этого сотрудникам полиции предоставлено право проверять документы, удостоверяющие личность граждан, в случае если имеются соответствующие основания, которые позволяют подозревать их в совершении преступления или полагать, что они находятся в розыске. Право проверять документы может быть реализовано также, если имеется повод к возбуждению в отношении гражданина дела об административном правонарушении или имеются достаточные основания для его задержания. Сотрудники полиции имеют право проверять у граждан, должностных лиц, общественных объединений и организаций разрешения и иные документы на совершение определенных действий или на осуществление определенного вида деятельности, контроль (надзор) за которыми возложен на полицию.

Полиция вправе участвовать в налоговых проверках по запросам налоговых органов РФ, а также получать в целях предупреждения, выявления и раскрытия преступлений в соответствии с законодательством РФ сведения, составляющие налоговую тайну.

В процессуальном производстве полиции находятся различные дела. В связи с этим уполномоченные на осуществление определенных процессуальных действий сотрудники полиции имеют право вызывать граждан и должностных лиц по расследуемым уголовным делам и делам об административных правонарушениях, а также в связи с проведением проверок по зарегистрированным в установленном порядке заявлениям и сообщениям о преступлениях, административных правонарушениях и происшествиях. Полиция также имеет право 
по материалам, находящимся у нее в производстве, запрашивать и получать на безвозмездной основе от государственных и муниципальных органов, общественных объединений, организаций, должностных лиц и граждан сведения, справки, документы, а также иную, необходимую для выполнения своих обязанностей информацию, в том числе персональные данные граждан. В случае необходимости полиция имеет право подвергать приводу граждан и должностных лиц, уклоняющихся без уважительных причин от явки по вызову.

Полиция имеет право запрашивать и получать от медицинских организаций сведения о гражданах, поступивших с ранениями и телесными повреждениями насильственного характера либо с ранениями и телесными повреждениями, полученными в результате ДТП, а также о гражданах, имеющих медицинские противопоказания или ограничения к водительской деятельности или деятельности, на осуществление которой требуется специальное разрешение.

Для получения необходимой информации полиция имеет право беспрепятственно, по предъявлении служебного удостоверения, посещать (в связи с расследуемыми уголовными делами или производством по делам об административных правонарушениях, проверкой зарегистрированных заявлений и сообщений о преступлениях, об административных правонарушениях) государственные и муниципальные органы, общественные объединения и организации. В ходе такого посещения сотрудники полиции имеют право знакомиться с необходимыми документами и материалами, в том числе с персональными данными граждан, имеющими отношение к расследованию уголовных дел, производству по делам об административных правонарушениях, проверке заявлений и сообщений о преступлениях, об административных правонарушениях, о происшествиях.

Сотрудники полиции, находясь на месте происшествия, имеют право требовать от граждан покинуть место совершения преступления или административного правонарушения, если это необходимо для проведения следственных действий, оперативно-разыскных мероприятий, документирования обстоятельств совершения преступления, административного правонарушения, фиксирования обстоятельств происшествия, сохранения следов преступления, административного правонарушения, происшествия и др.

Процессуальные права. В пределах своей компетенции сотрудники полиции имеют право составлять протоколы об административных правонарушениях, собирать доказательства, применять меры обеспечения производства по делам об административных правонарушениях. Они вправе производить в порядке, предусмотренном УПК РФ, следственные и иные процессуальные действия, проводить оперативно-разыскные мероприятия, объявлять розыск и принимать меры по розыску лиц, совершивших преступления или подозреваемых и обвиняемых в их совершении. Полиция вправе разыскивать иных лиц, розыск которых на нее возложен, объявлять розыск и принимать меры по розыску похищенных или угнанных транспортных средств, похищенного имущества, а также имущества, подлежащего конфискации.

К этой группе относятся также права полиции по доставлению, задержанию, личному досмотру граждан и др. Сотрудники полиции имеют право доставлять граждан в служебное помещение полиции, помещение муниципального органа, иное служебное помещение в целях решения вопроса о задержании гражданина (при невозможности решения данного вопроса на месте), установления личности гражданина, в случае если имеются основания полагать, что он находится в розыске как скрывшийся от органов дознания, следствия или суда либо как уклоняющийся от исполнения уголовного наказания. Доставление также может быть осуществлено для защиты гражданина от непосредственной угрозы его жизни и здоровью в случае, если он не способен позаботиться о себе, либо если опасности невозможно избежать иным способом.

Особо следует сказать о праве сотрудников полиции доставлять граждан, находящихся в общественных местах в состоянии алкогольного, наркотического или токсического опьянения и утративших способность самостоятельно передвигаться или ориентироваться в окружающей обстановке. Таких людей сотрудники полиции доставляют в медицинские организации, в случае необходимости направляют и (или) доставляют на медицинское освидетельствование в медицинские организации для определения наличия в организме алкоголя или наркотических средств. Это нужно, если результат освидетельствования необходим для подтверждения либо опровержения факта совершения соответствующим человеком преступления или административного правонарушения и в конечном счете для расследования по уголовному делу, а также 
для объективного рассмотрения дела об административном правонарушении.

Полиция вправе доставлять несовершеннолетних, совершивших правонарушения или антиобщественные действия, а также безнадзорных и беспризорных в центры временного содержания для несовершеннолетних правонарушителей (органов внутренних дел), в специализированные учреждения для несовершеннолетних, нуждающихся в социальной реабилитации, либо в служебное помещение полиции.

Доставленных лиц сотрудники полиции вправе в установленном процессуальном порядке подвергнуть личному досмотру, а также осуществить досмотр находящихся при них вещей. Кроме того, сотрудники полиции вправе досмотреть их транспортные средства при наличии данных, свидетельствующих о том, что эти граждане имеют при себе оружие, боеприпасы к оружию, взрывчатые вещества, взрывные устройства, наркотические средства, психотропные вещества либо ядовитые или радиоактивные вещества. По результатам досмотра сотрудники полиции должны изъять указанные предметы, средства и вещества при отсутствии законных оснований для их ношения или хранения. Сотрудники полиции вправе принимать участие в досмотре пассажиров, их ручной клади и багажа на железнодорожном, водном или воздушном транспорте, метрополитене либо осуществлять такой досмотр самостоятельно в целях изъятия вещей и предметов, запрещенных для перевозки транспортными средствами.

Полиция наделена правом производить регистрацию, фотографирование, аудио-, кино- и видеосъемку, дактилоскопирование лиц, задержанных по подозрению в совершении преступления, заключенных под стражу, обвиняемых в совершении преступления, подвергнутых административному наказанию в виде административного ареста, иных задержанных лиц, если в течение установленного срока задержания достоверно установить их личность не представилось возможным.

Полиция вправе формировать, вести и использовать банки данных оперативно-справочной, криминалистической, экспертно-криминалистической, разыскной и иной информации.

Права по охране общественного порядка и обеспечению общественной безопасности. В целях охраны общественного порядка и обеспечения общественной безопасности сотрудники полиции наделены правом патрулировать населенные пункты и общественные места, оборудовать при необходимости контрольные и контрольно-пропускные пункты, выставлять посты и заслоны, использовать другие формы охраны общественного порядка, осуществлять меры наблюдения за ходом социальной реабилитации лиц, освобожденных из мест лишения свободы.

Полиция имеет право вносить в установленном порядке руководителям и должностным лицам организаций обязательные для исполнения представления об устранении причин и условий, способствующих реализации угроз безопасности граждан и общественной безопасности, совершению преступлений и административных правонарушений. Законодатель наделил полицию также правом осуществлять в целях обеспечения безопасности граждан и общественного порядка совместно с организаторами публичных и массовых мероприятий личный осмотр граждан и находящихся при них вещей при проходе на территории сооружений, на участки местности либо в общественные места, где проводятся такие мероприятия. Следует иметь в виду, что в случае отказа гражданина подвергнуться личному осмотру полиция имеет право не допускать его в вышеперечисленные места. Полиция имеет право применять в период действия военного или чрезвычайного положения, а также в период проведения контртеррористической операции различные меры принуждения и временные ограничения, которые установлены законом.

Права в сфере обеспечения транспортной безопасности. При обеспечении безопасности дорожного движения полиция наделяется рядом прав, в том числе правом останавливать транспортные средства, если это необходимо для выполнения возложенных на полицию обязанностей по обеспечению безопасности дорожного движения, проверять документы на право пользования и управления ими, документы на транспортные средства и перевозимые грузы, наличие страхового полиса обязательного страхования гражданской ответственности владельца транспортного средства и другие документы.

Полиция также имеет право: осуществлять (с участием водителей или граждан, сопровождающих грузы) осмотр транспортных средств и грузов при подозрении, что они используются в противоправных целях, с составлением соответствующего акта; задерживать транспортные средства, находящиеся в розыске; при наличии оснований временно ограничивать или запрещать дорожное движение, а при необходимости изменять организацию 
движения на отдельных участках дорог в целях создания необходимых условий для безопасного движения транспортных средств и пешеходов или запрещать дорожное движение на железнодорожных переездах, не отвечающих правилам их содержания в безопасном для дорожного движения состоянии и т.п.

В пределах своей компетенции полиция имеет право запрещать проведение на дорогах ремонтно-строительных и других работ, осуществляемых с нарушением требований нормативных правовых актов в области обеспечения безопасности дорожного движения, а также задерживать транспортные средства и отстранять водителей от управления транспортными средствами. Кроме того, полиция имеет право запрещать эксплуатацию автомототранспортных средств и прицепов к ним, тракторов и других самоходных машин в целом ряде случаев, определенных законом.

При осуществлении контроля за обеспечением авиационной безопасности в области гражданской авиации полиция имеет право проводить проверки соблюдения правил предполетного досмотра, пропускного и внутриобъектового режимов, выдавать руководителям соответствующих организаций обязательные для исполнения предписания об устранении выявленных нарушений требований авиационной безопасности и проверять исполнение этих предписаний. При наличии информации о возможном нарушении требований авиационной безопасности на воздушном судне сотрудники полиции могут сопровождать его во время полета, задерживать багаж, грузы и почту, содержащие предметы и вещества, запрещенные к перевозке воздушными судами.

Права в сфере обеспечения разрешительной деятельности. Полиция вправе проводить проверки мест производства, хранения, торговли, коллекционирования и экспонирования оружия, мест производства патронов к оружию и составных частей патронов, а также проверки объектов, где они обращаются, мест утилизации боеприпасов. В этом направлении полиция имеет право: согласовывать требования к содержанию программ подготовки лиц в целях изучения правил безопасного обращения с оружием и приобретения навыков безопасного обращения с оружием; устанавливать порядок проверки знания правил безопасного обращения с оружием, а также участвовать в проверке таких знаний и навыков в этих организациях; проводить проверки мест хранения и использования специальных средств в частных охранных ор- ганизациях, а по результатам проверок выдавать гражданам и должностным лицам обязательные для исполнения предписания об устранении выявленных нарушений правил оборота оружия, боеприпасов, патронов к оружию и специальных средств. В случаях, установленных законом, сотрудники полиции вправе изымать оружие, боеприпасы к нему, ограничивать деятельность соответствующих объектов.

Полиция наделена правом продлевать срок действия, а также принимать решение о приостановлении срока действия или об аннулировании удостоверения (дубликата удостоверения) частного охранника. Сотрудники полиции имеют право: входить беспрепятственно (по предъявлении служебного удостоверения) в помещения, занимаемые частными детективами и частными охранными организациями, осматривать места хранения специальных средств и огнестрельного оружия; проверять организацию охраны, осуществляемой частными охранными организациями, при наличии оснований выдавать обязательные для исполнения предписания об устранении выявленных нарушений правил частной детективной (сыскной) и охранной деятельности.

Иные права. Федеральный закон от 7 февраля 2011 г. «0 полиции» ${ }^{1}$ дает право полицейским привлекать граждан с их согласия к внештатному сотрудничеству, а также устанавливать негласное сотрудничество с гражданами, изъявившими желание конфиденциально оказывать содействие полиции на безвозмездной или возмездной основе. Полиция также может объявлять о назначении вознаграждения за помощь в раскрытии преступлений и задержании лиц, их совершивших, и выплачивать его гражданам, поощрять граждан, оказавших помощь полиции в выполнении возложенных на нее обязанностей.

Выполняя свои обязанности, полиция наделена правом использовать на безвозмездной основе возможности СМИ для размещения информации в целях установления обстоятельств совершения преступлений, лиц, их совершивших, а также для розыска лиц, скрывшихся от органов дознания, предварительного следствия или суда, и лиц, пропавших без вести. При необходимости сотрудники полиции могут беспрепятственно пользоваться в служебных целях средствами связи, принадлежащими государственным предприятиям, учреждениям и организациям.

1 Собрание законодательства РФ. - 2011. - № 7. - Ст. 900. 
Согласно Федеральному закону «0 полиции» ее сотрудники получили право в случаях, не терпящих отлагательства, использовать транспортные средства, принадлежащие государственным и муниципальным органам, общественным объединениям и организациям, а в исключительных случаях - и транспортные средства, принадлежащие гражданам. Такое право предоставляется полиции для пресечения преступлений, преследования лиц, их совершивших или подозреваемых в их совершении, доставления в медицинские организации граждан, нуждающихся в срочной медицинской помощи, отбуксировки с места ДТП поврежденных транспортных средств, проезда к месту совершенного преступления, административного правонарушения, происшествия. При этом водители отстраняются (при необходимости) от управления этими транспортными средствами, с возмещением в установленном законом порядке по требованию владельцев транспортных средств понесенных ими расходов либо причиненного им материального ущерба.

Обязанности полиции. Полиция в целях реализации возложенных на нее задач выполняет целый ряд обязанностей, которые касаются самых разнообразных направлений ее правоохранительной деятельности. Условно обязанности, возложенные на полицию, можно подразделить на ряд групп. Одна группа обязанностей касается деятельности полиции, которая связана с фиксацией и процессуальным оформлением материалов о преступлениях, административных правонарушениях, чрезвычайных происшествиях. Другая группа обязанностей касается вопросов охраны общественного порядка и обеспечения общественной безопасности, а также оказания помощи гражданам, пострадавшим в результате каких-либо происшествий или правонарушений. Особую группу обязанностей полиции составляют обязанности, связанные с обеспечением безопасности дорожного движения, осуществлением разрешительной деятельности, обеспечением уголовной политики, обязанности по противодействию преступности, административным правонарушениям, а также оказанию содействия другим органам государственной власти и управления в реализации их полномочий.

Говоря непосредственно о содержании деятельности полиции, следует отметить, что ее работа зачастую начинается с приема и регистрации (в том числе в электронной форме) заявлений и сообщений о преступлениях, об административных правонарушениях, а также заявлений о различ- ных происшествиях. По принятым заявлениям в пределах своей компетенции сотрудники полиции проводят соответствующую работу, осуществляют сбор материалов, документов, а также иной информации. О проделанной проверочной работе по обращению информируются заявители в течение 24 ч. Информация, которая собрана в результате проведенной работы по соответствующему заявлению, может передаваться по подведомственности в другие органы государственной власти, правоохранительные органы, а также в оперативные и следственные подразделения.

Учет и регистрация заявлений о преступлениях, административных правонарушениях - важная составляющая в работе полиции. Это направление работы полиции находится под жестким контролем руководителей органов внутренних дел самого различного уровня, а также органов прокуратуры. Осуществляя работу с заявлениями, полиция обязана выдавать заявителям (на основании их личных обращений) уведомления о приеме и регистрации их письменных заявлений о преступлениях, об административных правонарушениях, а также о происшествиях.

Получив информацию о преступлении или административном правонарушении (происшествии), полиция обязана прибыть незамедлительно на место совершения соответствующего противоправного деяния (место происшествия), в случае, если это деяние продолжается, пресечь его и как можно быстрее устранить угрозы безопасности граждан и общественной безопасности. После пресечения противоправного деяния сотрудники полиции обязаны документировать обстоятельства совершения преступления, административного правонарушения, происшествия, а также обеспечить сохранность следов преступления, административного правонарушения, происшествия. Эта работа имеет большое значение для объективного рассмотрения соответствующего дела, определения виновности лица или лиц, которые совершили противоправное деяние. Необходимо подчеркнуть, что сотрудник полиции должен четко понимать, насколько эта работа важна для дальнейшего процессуального разбирательства по делу.

Достаточно часто на месте происшествия оказываются люди, получившие травмы, находящиеся в беспомощном состоянии. В этом случае сотрудник полиции обязан незамедлительно оказать первую помощь лицам, пострадавшим от преступлений, административных правонарушений и несчастных случаев, а также лицам, находящимся в беспо- 
мощном состоянии, либо в состоянии, опасном для их жизни и здоровья. Особенно важно это делать, если специализированная (врачебная) помощь не может быть получена такими людьми своевременно. От умелых действий сотрудников полиции по оказанию помощи пострадавшим зачастую может зависеть жизнь и здоровье человека.

Работая на месте происшествия, сотрудникам полиции в ряде случаев приходиться принимать меры по идентификации лиц, которые по состоянию здоровья, возрасту или иным причинам не могут сообщить сведения о себе. Полицейский должен предпринять максимум усилий для установления личности соответствующего лица, при этом он может использовать помощь граждан, которым известна какая-либо информация о таком человеке, учеты медицинских учреждений и т.п. Бывают случаи, когда сотрудники полиции принимают самое непосредственное участие в мероприятиях по идентификации неопознанных трупов. Для этого должны использоваться информация, полученная из свидетельских показаний, помощь общественности, изучаться документы, находящиеся при неопознанном трупе. Для установления данных о неопознанном трупе достаточно часто используется информация, которая содержится в различных учетах и картотеках органов внутренних дел или учреждений здравоохранения и т.д.

Очень важной является работа полиции по принятию неотложных мер при чрезвычайных ситуациях, которые могут касаться спасения граждан, охраны их имущества, оставшегося без присмотра. В этом случае полиция обязана обеспечивать сохранность найденных и сданных документов, вещей, кладов, ценностей и другого имущества, гарантировать их возврат законным владельцам, либо осуществлять передачу ценностей или иного имущества в соответствующие государственные или муниципальные органы.

Полиция обязана содействовать бесперебойной работе спасательных служб, обеспечивать общественный порядок при проведении карантинных мероприятий, в частности, при эпидемиях и эпизоотиях.

Помимо участия в ликвидации последствий чрезвычайных ситуаций, полиция также обязана участвовать в обеспечении режима военного положения, а также режима чрезвычайного положения в случае их введения на территории Российской Федерации или в отдельных ее местностях.

На полицию возлагается целый ряд обязанностей по предупреждению и профилактике пра- вонарушений среди самых различных категорий граждан. Сотрудниками полиции должна проводиться серьезная работа по выявлению причин преступлений и административных правонарушений, а также условий, способствующих их совершению. В пределах своей компетенции сотрудники полиции обязаны принимать меры по их устранению. Важная задача полиции - выявление лиц, которые имеют намерение совершить преступление. С такими лицами необходимо проводить индивидуальную профилактическую работу в форме бесед, различных разъяснительных мероприятий и т.п. Особое направление работы полиции по профилактике правонарушений - работа с безнадзорными несовершеннолетними и несовершеннолетними, которые совершили незначительные административные правонарушения. Составной частью профилактической работы с такой категорией граждан может являться деятельность полиции, связанная с пропагандой правовых знаний.

На полицию возложен целый ряд обязанностей в сфере охраны общественного порядка и обеспечения общественной безопасности. Сотрудник полиции является ключевой фигурой при осуществлении охраны общественного порядка в местах нахождения граждан, функционирования какойлибо социальной инфраструктуры, транспорта и т.д. В связи с этим вполне логичным видится обязанность полиции обеспечивать безопасность граждан и общественный порядок на улицах, площадях, стадионах, в скверах, парках, на транспортных магистралях, вокзалах, в аэропортах, морских и речных портах и других общественных местах. Полиция также обеспечивает охрану общественного порядка при проведении собраний, митингов, демонстраций, шествий и других публичных мероприятий.

Осуществляя свою деятельность, полиция не оставляет без внимания и вопросы обеспечения имущественной безопасности физических и юридических лиц. Так, в компетенцию полиции входит охрана на договорной основе имущества граждан и организаций, а также объектов, подлежащих обязательной охране со стороны полиции. Полиция обязана обеспечить оперативное реагирование на сообщения о срабатывании охранно-пожарной и тревожной сигнализации на подключенных к пультам централизованного наблюдения объектах, охрана которых осуществляется с помощью технических средств охраны; проводить инспектирование подразделений охраны юридических 
лиц с особыми уставными задачами и подразделений ведомственной охраны; обеспечивать во взаимодействии с органами федеральной службы безопасности охрану дипломатических представительств, консульских учреждений, иных официальных представительств иностранных государств, а также представительств международных организаций, если такая охрана предусмотрена международными договорами РФ.

Проводя работу по охране общественного порядка и обеспечению общественной безопасности, сотрудники полиции обязаны пресекать самые разные административные правонарушения, а также осуществлять производство по делам об административных правонарушениях, которые отнесены к компетенции полиции.

Составной частью обеспечения общественной безопасности является деятельность полиции в сфере миграционных процессов, а также контроль за соблюдением иностранными гражданами и лицами без гражданства порядка временного или постоянного проживания, временного пребывания в Российской Федерации, въезда в Российскую Федерацию, выезда из Российской Федерации и транзитного проезда через территорию РФ.

Развитие транспортного комплекса и транспортной инфраструктуры объективно предполагает участие полиции в вопросах обеспечения транспортной безопасности. Полиция осуществляет целый ряд обязанностей по обеспечению государственного контроля (надзора) за соблюдением правил, стандартов, технических норм и иных требований нормативных документов в области обеспечения безопасности дорожного движения. Сотрудники ГИБДД регулируют дорожное движение, оформляют документы о ДТП, осуществляют государственный учет основных показателей состояния безопасности дорожного движения и др. Важной обязанностью полиции в этом направлении является прием экзаменов на право управления автомототранспортными средствами, трамваями, троллейбусами и выдача по их результатам водительских удостоверений. Полиция обязана регистрировать автомототранспортные средства и прицепы к ним, а также выдавать в установленных случаях свидетельства о допуске таких транспортных средств к перевозке опасных грузов, согласовывать маршруты движения транспортных средств, осуществляющих перевозку крупногабаритных и тяжеловесных грузов. В сфере функционирования авиационного транспорта полиция в пределах своей компетенции обязана участвовать в обеспечении авиационной безопасности в области гражданской авиации, охранять аэропорты и объекты их инфраструктуры, выносить заключения о возможности допуска к работе тех или иных лиц в службе авиационной безопасности и др.

В современный период для всех государств особо важными являются вопросы борьбы с терроризмом и экстремизмом. Эта проблема актуальна и для нашей страны. В целях противодействия терроризму и экстремизму практически в каждом государстве создаются специализированные службы. Несмотря на это, и органы полиции также проводят целый комплекс мероприятий, а также выполняют ряд обязанностей в этом направлении. Так, полиция осуществляет меры, направленные на предупреждение, выявление и пресечение экстремистской деятельности граждан, общественных объединений, религиозных и иных организаций. Кроме того, полиция участвует в мероприятиях по противодействию терроризму, обеспечению правового режима контртеррористической операции. Полиция также участвует в обеспечении защиты потенциальных объектов террористических посягательств и мест массового пребывания граждан. Уполномоченные подразделения полиции осуществляют проведение экспертной оценки состояния антитеррористической защищенности и безопасности объектов большой социальной значимости.

В сфере лицензионно-разрешительной деятельности полиция осуществляет выдачу гражданам и организациям (при наличии оснований, предусмотренных законом) лицензий на приобретение гражданского и служебного оружия. Полиция также выдает лицензии на осуществление деятельности по торговле оружием и патронами к нему; лицензии на осуществление деятельности по экспонированию и (или) коллекционированию оружия; разрешения на хранение или хранение и ношение гражданского и служебного оружия, на хранение и ношение наградного оружия, на транспортирование оружия и др. При этом в обязанности полиции вменяется контроль за оборотом гражданского, служебного и наградного оружия, а также боеприпасов. Кроме того, полиция осуществляет контроль за сохранностью и техническим состоянием боевого ручного стрелкового и служебного оружия, находящегося во временном пользовании у граждан и организаций, а также за соблюдением гражданами и организациями законодательства в области оборота такого оружия. На полицию возложено 
исполнение и ряда иных полномочий в рассматриваемой сфере.

Отдельно следует отметить, что полиция обязана изымать у граждан и должностных лиц документы, имеющие признаки подделки, а также вещи, изъятые из гражданского оборота, или ограниченно оборотоспособное имущество, или имущество, находящееся у лица без специального разрешения. Такое изъятие должно быть надлежащим образом оформлено, в частности составлением протокола и вручением его копии указанным гражданам или должностным лицам.

Развитие рыночных отношений повлекло за собой создание предприятий, которые занимаются негосударственной частной детективной и охранной деятельностью. Субъектом, который контролирует работу соответствующих негосударственных «правоохранительных» структур, является полиция. Она выдает лицензии на осуществление частной детективной (сыскной) деятельности и на осуществление охранной деятельности, проводит периодические проверки частных охранников и работников юридических лиц с особыми уставными задачами на пригодность к действиям в условиях, связанных с применением огнестрельного оружия и специальных средств. Поэтому вполне логичен контроль полиции за деятельностью частных детективов и частных охранных организаций.

В сфере реализации уголовного судопроизводства, исполнения уголовного и уголовно-процессуального законодательства полиция вправе возбуждать уголовные дела, производить дознание по уголовным делам, производство предварительного следствия по которым необязательно, выполнять неотложные следственные действия по уголовным делам, производство предварительного следствия по которым обязательно. Полиция (в пределах своих полномочий) обязана исполнять решения суда (судьи), письменные поручения следователя, руководителя следственного органа, органа дознания о производстве отдельных следственных действий, проведении оперативно-разыскных мероприятий, задержании лиц, подозреваемых и обвиняемых в совершении преступлений, а также оказывать содействие в производстве иных процессуальных действий.

Для раскрытия преступлений полиция осуществляет оперативно-разыскную деятельность, ведет розыск лиц, совершивших преступления или подозреваемых и обвиняемых в их совершении, лиц, скрывшихся от органов дознания, следствия или суда. Полиция обязана искать несовершеннолетних, самовольно ушедших из семей или специализированных учреждений для несовершеннолетних, нуждающихся в социальной реабилитации, а также несовершеннолетних, самовольно ушедших из специальных учебно-воспитательных учреждений закрытого типа.

В целях обеспечения безопасности участников уголовного процесса полиция обязана осуществлять государственную защиту потерпевших, свидетелей и иных участников уголовного судопроизводства, судей, прокуроров, следователей, а также должностных лиц правоохранительных и контролирующих органов.

В случаях, предусмотренных законом, полиция осуществляет розыск лиц, уклоняющихся от недобровольной госпитализации, назначенной судом в связи с наличием у лица психического расстройства, а также лиц, уклоняющихся от исполнения назначенных судом принудительных мер медицинского характера, лиц, пропавших без вести.

В обязанности полиции входит оказание содействия органам здравоохранения в доставлении в медицинские организации по решению суда лиц, уклоняющихся от явки по вызову в эти организации; полиция участвует совместно с органами здравоохранения в наблюдении за лицами, страдающими психическими расстройствами, больными алкоголизмом или наркоманией, в случае, если они представляют опасность для окружающих. Эта работа необходима в целях предупреждения совершения такими лицами преступлений и административных правонарушений. Полиция обязана оказывать содействие медицинским работникам в осуществлении назначенной судом недобровольной госпитализации лиц в медицинские организации, а также обеспечивать медицинским работникам безопасные условия для доступа к этим лицам и их осмотра.

Полиция производит розыск похищенного имущества и устанавливает имущество, подлежащее конфискации. Полиция является одним из субъектов, осуществляющих реализацию уголовной политики, в этом направлении она оказывает содействие учреждениям и органам уголовно-исполнительной системы в осуществлении розыска и задержании лиц, совершивших побег из-под стражи, лиц, уклоняющихся от отбывания уголовного наказания, и др.

Полиция в специально отведенных для этого местах содержит, охраняет и конвоирует задержан- 
ных и (или) заключенных под стражу лиц, в том числе и подвергнутых административному аресту. Полиция осуществляет административный надзор за соблюдением лицами, освобожденными из мест лишения свободы, установленных для них судом запретов и ограничений. Кроме того, полиция участвует в осуществлении контроля за поведением осужденных, которым назначено наказание, не связанное с лишением свободы, или наказание в виде лишения свободы условно. В обязанности полиции также входит проведение государственной дактилоскопической регистрации и государственной геномной регистрации.

При выполнении возложенных на нее задач полиция обязана оказывать содействие различным органам государственной власти и управления, а также их должностным лицам. Так, полиция оказывает содействие пограничным органам федеральной службы безопасности в проведении мероприятий по защите государственной границы РФ. Полиция обязана принимать меры по обеспечению действующего законодательства в ходе избирательных кампаний, при подготовке и проведении референдумов. Исходя из своих полномочий, полиция обязана информировать различные избирательные комиссии о фактах выявленных нарушений и принятых в связи с этим мерах, предоставлять по запросам избирательных комиссий информацию о наличии неснятой или непогашенной судимости у лиц, являющихся кандидатами на различные выборные должности в органы государственной власти и управления. В ходе избирательных кампаний полиция осуществляет охрану помещений, где хранятся бюллетени для голосования на выборах, участвует в обеспечении безопасности граждан и общественного порядка в помещениях для голосования и на территориях вокруг них. В пределах своей компетенции полиция оказывает содействие депутатам различного уровня, лицам, которые зарегистрированы в качестве кандидатов на выборные должности, если им оказывается противодействие или угрожает опасность. При взаимодействии с органами власти, полиция информирует Президента России, Правительство РФ, а также высших должностных лиц субъектов Федерации и выборных должностных лиц местного самоуправления о состоянии правопорядка в стране или на соответствующей территории.

В целях соблюдения налогового законодательства физическими и юридическими лицами полиция направляет материалы в налоговый орган для принятия по ним решения при выявлении обстоятельств, требующих совершения действий, отнесенных законом к полномочиям налоговых органов РФ.

\section{Библиография:}

1. Аврутин, Ю. Е. Полиция и милиция в механизме обеспечения государствен-ной власти в России / Ю. Е. Аврутин. СПб. : Юрид. центр Пресс, 2003.

2. Административное право и административная деятельность органов внут-ренних дел / под ред. Л. Л. Попова. М. : Акад. МВД СССР, 1990.

3. Бельский, К. С. Полицейское право / под ред. А. В. Куракина. - М. : Дело и сервис, 2004.

4. Веремеенко, И. И. Механизм административно-правового регулирования в сфере охраны общественного порядка. - Ч. 1 : Предмет и понятие; Ч. 2 : Элементы и формы реализации права в механизме административноправового регулирования в сфере охраны общественного порядка / И. И. Веремеенко. - М. : ВНИИ МВД СССР, 1981-1982.

5. Еропкин, М. И. Управление в области охраны общественного порядка / М. И. Еропкин. - М. : Юрид. лит., 1965.

6. Зубач, А. В. Административная деятельность органов внутренних дел в во-просах и ответах / А. В. Зубач, А. Н. Кокорев. - М. : Щит-М, 2005.

7. Куракин А.В., Костенников М.В. Административный процесс и его реализации в деятельности полиции // NB: Российское полицейское право. - 2013. - 4. - С. 1 - 44. DOI: 10.7256/2306-4218.2013.4.9250. URL: http://www.enotabene.ru/pm/article_9250.html

8. Куракин А.В. Компетенция полиции в сфере реализации законодательства об административных правонарушениях // NB: Административное право и практика администрирования. - 2013. - 4. - С. 28 - 48. DOI: 10.7256/23069945.2013.4.8841. URL: http://www.e-notabene.ru/al/article_8841.html

9. Костенников М.В., Куракин А.В. К вопросу об основании административной ответственности в российском праве // NB: Административное право и практика администрирования. - 2013. - 10. - С. 75 - 88. DOI: 10.7256/23069945.2013.10.10153. URL: http://www.e-notabene.ru/al/article_10153.html

10. Куракин А.В., Костенников М.В. Принципы организации и деятельности российской полиции // NB: Российское полицейское право. - 2013. - 2. - С. 22 - 49. DOI: 10.7256/2306-4218.2013.2.799. URL: http://www.e-notabene.ru/ pm/article_799.html 


\section{References (transliterated):}

1. Avrutin, Yu. E. Politsiya i militsiya v mekhanizme obespecheniya gosudarstven-noi vlasti v Rossii / Yu. E. Avrutin. - SPb. : Yurid. tsentr Press, 2003.

2. Administrativnoe pravo i administrativnaya deyatel'nost' organov vnut-rennikh del / pod red. L. L. Popova. - M. : Akad. MVD SSSR, 1990.

3. Bel'skii, K. S. Politseiskoe pravo / pod red. A. V. Kurakina. - M. : Delo i servis, 2004.

4. Veremeenko, I. I. Mekhanizm administrativno-pravovogo regulirovaniya v sfere okhrany obshchestvennogo poryadka. - Ch. 1 : Predmet i ponyatie; Ch. 2 : Elementy i formy realizatsii prava v mekhanizme administrativno-pravovogo regulirovaniya v sfere okhrany obshchestvennogo poryadka / I. I. Veremeenko. - M. : VNII MVD SSSR, 1981-1982.

5. Eropkin, M. I. Upravlenie v oblasti okhrany obshchestvennogo poryadka / M. I. Eropkin. - M. : Yurid. lit., 1965.

6. Zubach, A. V. Administrativnaya deyatel'nost' organov vnutrennikh del v vo-prosakh i otvetakh / A. V. Zubach, A. N. Kokorev. - M. : Shchit-M, 2005.

7. Kurakin A.V., Kostennikov M.V. Administrativnyi protsess i ego realizatsii v deyatel'nosti politsii // NB: Rossiiskoe politseiskoe pravo. - 2013. - 4. - C. 1 - 44. DOI: 10.7256/2306-4218.2013.4.9250. URL: http://www.e-notabene.ru/pm/ article_9250.html

8. Kurakin A.V. Kompetentsiya politsii v sfere realizatsii zakonodatel'stva ob administrativnykh pravonarusheniyakh // NB: Administrativnoe pravo i praktika administrirovaniya. - 2013. - 4. - C. 28 - 48. DOI: 10.7256/2306-9945.2013.4.8841. URL: http://www.e-notabene.ru/al/article_8841.html

9. Kostennikov M.V., Kurakin A.V. K voprosu ob osnovanii administrativnoi otvetstvennosti v rossiiskom prave // NB: Administrativnoe pravo i praktika administrirovaniya. - 2013. - 10. - C. 75 - 88. DOI: 10.7256/2306-9945.2013.10.10153. URL: http://www.e-notabene.ru/al/article_10153.html

10. Kurakin A.V., Kostennikov M.V. Printsipy organizatsii i deyatel'nosti rossiiskoi politsii // NB: Rossiiskoe politseiskoe pravo. - 2013. - 2. - C. 22 - 49. DOI: 10.7256/2306-4218.2013.2.799. URL: http://www.e-notabene.ru/pm/article_799. html 